\title{
Population Policy as a Means for Bio-Politics: The Cases of Romania and China
}

\author{
Pelin Önder Erol \\ Department of Sociology, Faculty of Letters, Ege University, \\ Izmir, Turkey \\ pelinondertr@yahoo.com
}

\begin{abstract}
After the discovery of "population" in modern society, domination over the body has been enacted by a set of interventions which are called regulatory control, or bio-politics by Michel Foucault. From the eighteenth century onwards, bio-politics has involved any kind of intervention which acts as means for forming the population according to the wills of those with power. This has led to an era of bio-politics in which fertility in particular has become regulated in accordance with political economy. Hence the body, especially the female body, has been reduced to an economic object by detaching her identity, personal aspirations and desires. In turn, sexuality becomes a subject of economic interventions through pronatalist and/or antinatalist politics. In either way, those interventions should be methodologically regarded as instruments of bio-politics. This paper specifically focuses on pronatalist and antinatalist politics as bio-political instruments in the well-known Romanian case and the Chinese case by drawing upon the Foucauldian perspective of bio-politics.
\end{abstract}

Keywords: Bio-politics, Fertility, Pronatalist policies, Antinatalist policies

\section{Introduction}

Three basic dynamics of demographic change are birth, death and migration. Among those, birth and migration are specifically the ones that are determined by individual decisions, but are also formed by several political implications on a macro level. The levels at which these dynamics appear and the kind of tendencies they exhibit is accomplished through the domination of bodies and the means of power. Foucault (1978) notes that since the eighteenth century power, which had previously been formed through the threat of death, began to be exercised by dominating the bodies of people. According to him, there are two ways to dominate bodies. The first one is called anatomo-politics, which means disciplining the body and making it obedient by increasing its abilities and utility. The second, which was formed later, is the discovery of the body as the foundation of the biological processes. Thus, it refers to 
"propagation, births and mortality, the level of health, life expectancy and longevity, with all the conditions that can cause these to vary. Their supervision was effected through an entire series of interventions and regulatory controls: a biopolitics of the population" (ibid: p.139). What Foucault (1992: p.109) pointed out was that with the emerging concept of bio-politics in the eighteenth century, governments have tried to rationalize questions about the living community as a population, a newly significant phenomenon. It is now the case that population statistics serve as an epistemological entity for the attempts of governments to regulate a population. Population statistics are built on the basis of the idea that "one body comes to equal another, that each death, birth, marriage, divorce and so on, comes to be equivalent of any other" (Curtis, 2002: p.529). It may be argued that exercising bio-politics and the discovery of the population are related since bio-politics can only be mobilized by gathering those population statistics. Thus, defining a population as an aggregation of individuals by taking the individuals as collective abstractions (Kligman, 1998: p.11) facilitates employing the coercive means of bio-politics.

Bio-politics may be understood as any attempt to regulate the population according to the demands of the government. A variety of techniques to control the population, having an effect on fertility, as well as on a set of demographic dynamics such as longevity, immigration, etc., are employed. Thus, the "bio-power" era begins (Foucault, 1978: p.140). In the era of bio-power, attempts are made to regulate fertility according to the political economy in which governments are engaging. The body, especially the female body, is degraded to an economic object by being detached from her individual identity, personal aspirations and desires. In a very general sense, being located at the junction of the 'body' and the 'population' for Foucault, sex displaces the former forms of power which had been sustained through the threat of destruction of the body, and now becomes the means and the ends of a power which is sustained through the regulation of the body. Thus, sexuality comes to be the theme of pronatalist or antinatalist policies undertaken by economic interventions (ibid: p.147).

Whether policies are pronatalist, and encourage an increase in population growth or they are antinatalist and aimed at limiting it, all initiatives for population regulation may be seen as a means for bio-politics if they are to establish a form of control over the body. This study is an attempt to display why and how Romania's harsh experience in accelerating population growth through increasing fertility in the 1960s, and China's antinatalist population policies following in quite the opposite direction between 1979-2016, should be seen as examples of these means through a Foucauldian perspective. First, the definitions of pronatalist and antinatalist policies will be discussed. Second, the development of pronatalist policies in Romania will be examined, categorizing it into two periods, the periods before and after the year 
1966 when the Decree No. 770 was put into force. Third, the course of China's antinatalist population policy, which was initiated in 1979 and was been implemented until 2015, will be introduced into the discussion. Finally, a conclusion will analyze the regulation and the control of populations exercised in different historical periods in the two countries. By reviewing the literature written on the two cases, the paper aims methodologically at revealing whether the population policies, with specific regard to those concerning fertility, may be considered to be the means of bio-politics from a Foucauldian view.

\section{Pronatalist and Antinatalist Policies}

"Pronatalist society is one in which people believe that married couples should reproduce or should want to reproduce" (Newman \& Grauerholz, 2002: p.327). In a pronatalist society people also have pronatalist values: for instance, a woman's very presence in the society is through giving birth. Indeed, both women's and men's societal status are mostly determined in that way. On the other hand, voluntarily childless couples are regarded as threats to society for dislocating the longestablished values (ibid).

Unlike pronatalism, antinatalism refers to a logic that reproduction should be limited for the common good of a society. By discouraging population growth, antinatalist policies of today aim at increasing the per capita income (Fanti \& Gori, 2009). Although antinatalist claims have now moved far away from a Malthusian apocalyptic vision, the idea behind them still relies upon the fact that too many people are hard to be supported for economic, social and environmental reasons. Accordingly, the idea can also be vigorously adopted by those individuals who believe that fewer children would be more manageable, both financially and socially, at the micro scale. In addition to the structural factors driven by modernization and urbanization, ideational changes bring forth a fertility decline in developed societies where individualism prevails. Van de Kaa (1989: p.11) explains this ideational change as a "shift from the era of the king-child with parents to that of the king-pair with a child". Concomitantly, total fertility rates ${ }^{1}$ have begun to fall well below the replacement fertility ${ }^{2}$ level in most of the developed world. Despite the fact that

\footnotetext{
1 "The expected number of children a woman who survives to the end of the reproductive age span will have during her lifetime if she experiences the given age-specific rates".

Reference: United Nations. 2003. Handbook on the Collection of Fertility and Mortality Data. 16 September 2017. <http://data.un.org/Glossary.aspx?q=total+fertility+rate>.

${ }^{2}$ Every two children born will replace their mother and father. However, because of a risk for dying before reaching fertile age and the sex ratio imbalance at birth $(1,05)$, an extra ratio of 0,1 is needed.
} 
fertility decline is not supported by the states in the developed world through antinatalist policies, antinatalism as a way of life predominates in individualistic societies. Fertility decline in developed countries is an outcome of a statistical aggregation of rational and voluntary behaviors of singular individuals, but not an outcome of enforced policies.

Pronatalist and antinatalist values, akin to all other values related to fertility, are shared and should be considered immaterial elements of culture. Attitudes and behaviors regarding fertility are products of diffusion in a sense. These orientations can be explained through diffusion theory, which may briefly be defined as "a perspective which maintains that the role of social interaction on fertility-related decisions is particularly important" (Önder Erol, 2011: p.22). According to a group of diffusion theorists, in societies speaking the same language, values, attitudes and behaviors concerning fertility are shared commonly (Johnson-Hanks, 2008: p.305). And it is also a correlate in diffusion theory that whether a society holds pronatalist or antinatalist values is a social construct.

On the other hand, a government's decision about following pronatalist or antinatalist policy may be irrelevant for fertility-related values of the society in question. For example, in some of the Eastern European countries, pronatalist policies, which have used a variety of practices ranging from incentives like lengthened paid maternity leave, family allowances, cash birth grants, access to new housing, and new taxes for childless couples (McIntyre, 1975: p.367) to serious disincentives like abortion bans, should be considered to be attempts to increase birth rates. Birth rates aimed at by pronatalist policies are higher than the replacement leve of fertility, which is a total fertility rate of 2.1 child per woman. It is only when this rate is exceeded that population growth can be achieved. As for antinatalist policies, as in the specific case of Chinese antinatalist policy, couples have been restricted to having only one child. Especially in the urban areas of China, couples who had more than one child had to face "loss of access to schools, medical care, factory jobs, housing, and social welfare" (Basten \& Jiang, 2014: p.494). The targeted fertility rate was 1.0, a rate which is below the replacement level, and a population decline in the long run was inevitable. To repeat, it may not be possible to draw a correspondence between the level a society holds pronatalist or antinatalist values and the likelihood of the government enforcing pronatalist/antinatalist policies. Therefore, when legislations and policies concerning reproduction are based on abstract ideological principles rather than socio-economic circumstances that affect

Reference: Rowland, D. T. Demographic Methods and Concepts, United Kingdom: Oxford University Press, 2006. 
humans' quality of life, the resulting outcomes can be tragic, especially for women and children (Kligman, 1998: p.2). Romania, as one of the Eastern European countries influenced by Soviet communism, argued that its success could only become possible with women's emancipation (Lenin, 2000: p.193-206). Yet it adopted the most stringent pronatalist policy between 1966 and 1989. The case of Romania is full of contradictions. In fact, in this era a set of problems developed in Romania, including an increase in the risk of maternal mortality due to abortion and an increase in the number of unwanted babies. Likewise, implementations in China, the outcomes of which are similar to those of the Romanian case but through different ways, caused a set of problems concerning the demographic structure which can only be revealed in the long-run, at the macro level. On the other hand, they also brought about tragic effects on individuals and families, at the micro level.

\section{The Development of Pronatalist Policies in Romania}

The overall trend of fertility decline in Europe began to be considered a problem as a labor force came to be needed. This was especially the case for the Eastern European countries that were aiming at rapid industrialization in the post-World War II period (Moskoff, 1980: p.597). Among European countries, Romania especially responded to this pressure in the 1960s with a set of extreme government interventions to boost fertility. Romania then experienced a baby boom just after the pronatalist policy had begun to be effectively implemented. This may be examined as two successive periods, the first of which is the period before those policies were put into force (pre-1966) and the second of which is the period during when those policies were strictly being exercised (between 1966 and 1989).

\section{a. Pre-1966 Period}

Fertility rates in Europe began to fall in the late 1800s. With an accompanying mortality decline, a demographic transition had begun in Western Europe. Although traditional birth control methods had been extensively used by the general public during the demographic transition (Szreter, Nye \& van Poppel: 2003), innovation, improvement and proliferation of modern contraceptive techniques played an important role in the fertility decline. This was because they served as an alternative and effective way for couples to limit the number of children they had, if they so desired.

Adoption of birth control methods by couples was mostly due to changes in social and economic structure. With industrialization and migration from rural to urban areas, the child is no longer considered to be an economic asset (Caldwell, 1976; 2005) and an old-age security (Kağıtçıbaş1, 1982). Another factor related to 
structural differentiation is that the educational status of women had risen, and therefore they occupied a higher share of the urban labor force.

Moreover, as Beck and Beck-Gernsheim (2004) noted, the demands of women to expand the scope of their power and to be emancipated from domestic roles enabled them to be individualized. This ideational change caused women, and even men, in Europe to have fewer children. In modern society self-identities have significant effects upon family and fertility behaviors. Reproduction in a reflexive modernity, compared to that in the pre-modern era when reproduction is highly associated with fate, becomes a matter of multiple choices (Giddens, 2010: p.273). Therefore, standard biographies are replaced by self-reflexive biographies in which individuals have to make their own decisions concerning the issues such as education, occupation, spouse and the number of desired children (Beck, 2014: p.205).

In Eastern European countries, fertility decline occurred for similar reasons. The share of the female labor force in Western countries has risen since World War II; the largest increase has been observed among married women (Giddens, 2010). According to Macura (1974), the fact that women gained higher prestige due to their increased share in labor force caused fertility to decline in the post-war period. Overall development, including mass education, has raised the educational level of women, as well as of the whole population. Concomitantly, this led to lower birth rates in the developing world, including Romania (Moskoff, 1980). In fact, according to research carried out in urban Bucharest in the 1960s, the desired number of children was 1,3 on average; whereas it was 0,7 for the women with higher education (Mehlan, 1966, as cited in Besemeres, 1980: p.37). Also, in this period, that women began to be employed in the urban industrial sector in socialist countries is another important factor for a fertility decline in the Eastern Europe. Following this shared pattern, Romania lead among the Eastern European countries, in that female labor was extensively utilized. In addition, the majority of families were in need of the financial contribution made by women to the household income (Moskoff, 1980). Intensive participation of women in the labor force caused a decline in fertility for several practical reasons. The question of who would take care of the children was the foremost one. Given that the state could not provide any solution to this problem; and the reduced grand-parenting role in childcare due to the dissolution of the extended family, women had some concerns about having more children (ibid). Women, who used up their energy after long working hours, had been considering that they might be unable to perform their affective roles. Therefore, they avoided having more children, knowing that they would feel the double burden otherwise. On the other hand, under harsh economic circumstances the income they provided was necessary. Briefly, in the Romanian case, while women were invited into working life, a significant reality was overlooked: If women were supposed to work 
intensively for the sake of the rapid industrialization, then social policies, such as providing childcare and hence reducing the double burden on women, should had been put into practice.

Throughout the pre-1966 period, Romania attempted to spur its economic development by transferring its agricultural labor force into an industrial one. As a part of the socialist ideology to press equal participation of both sexes into employment, economic planners had recommended that the female labor force should be integrated into the Romanian economy. "To facilitate the projects aimed at radical social change, the young communist government needed first to destroy the institutions, norms, and values of the preceding system. It thus took aim at traditional family structures" (Kligman, 1998: p.23). This was followed by a set of practices to enlarge the scope of freedom for family planning through a set of programs such as making contraceptive techniques and abortion available to all.

However, the economic program of the period caused indirect and unforeseen consequences, including a rapid fertility decline (Kligman, 1998; Moskoff, 1980). In fact, in Romania the crude birth rate, ${ }^{3}$ which had been 24,2 in 1956 , fell to 14,3 within as short a period as a decade (Berelson, 1979; Moskoff, 1980). Undoubtedly, this sharp decline was due mostly to liberalizing access to abortion in 1957. Actually, from that year on, until 1966, the year when Decree number 770 was introduced, abortion was the primary birth control method employed (Moskoff, 1980, Berelson, 1979; Teitelbaum, 1972; Legge \& Alford, 1986).

\section{b. The Period of a Strict Pronatalist Policy (1966-1989)}

Lowered fertility has dominated both Western and Eastern Europe in the post-war period. Although in both regions, the idea that fertility decline might be a threat to the economy was shared, the ways in which they managed it were significantly different (Legge \& Alford, 1986). Democratic governments consider reproduction to be a matter of individual choice and prioritize choice over demographic policies that are planned for governmental interests (McIntosh, 1983 as cited in Legge \& Alford, 1986). In other words, reproduction in democratic countries occurs in a way that sexuality is associated with personal fulfillment, which is defined by Giddens (2005: p.125) as "effective individualism". On the other hand, as can be seen from

\footnotetext{
3 "A vital statistics summary rate based on the number of live births occurring in a population during a given period of time, usually a calendar year, i.e., the number of live births occurring among the population of a given geographical area during a given year, per 1,000 mid-year total population of the given geographical area during the same year". Reference: United Nations. 2001. Principles and Recommendations for a Vital Statistics System, Revision 2 2001, 19 October 2017. <http://data.un.org/Glossary.aspx?q=crude+birth+rate>.
} 
the Romanian case that this study partly focuses on, authoritarian states of Eastern Europe in this period adopted ways of regulating the fertility behavior of their citizens through exercising bio-power.

According to Besemeres (1980: p.262), states can follow three possible ways to intervene in population policies. First, policies may be economic measures such as family benefits, or maternity and childcare leaves. The second group of strategies is made up of moral propaganda campaigns through mass media and organizations. And the third group of strategies is composed of legal-administrative measures, such as legal incentives and disincentives with regard to birth control mechanisms. According to this classification, the methods followed by Romania in the post-1966 period were legal-administrative strategies rather than economic and moral ones. In other words, Romania aimed at increasing birth rates through direct interventions into female bodies, instead of making an ideational change in fertility behavior through articulating encouraging discourses or providing family supports. In short, the means of pronatalist policy of Romania of this period were marked by coercion and oppression.

The government had suddenly begun to take quite an opposite tack in its quest for an economic growth. Instead of employing the available female labor force, the government sought natural population growth as the prerequisite for industrialization and economic development, and had targeted a population reaching 25 billion by 1990 and 30 billion by 2000 (Trebici, 1976 as cited in Berelson, 1979). The expectation was that a younger and larger population would mean a greater labor force. This is an exact example of what Foucault (1992, p. 110) identifies as "the reason of the state". By this, he argues that the state grows stronger through population growth. Throughout the construction of socialism, reproduction of a labor force had been of particularly great importance (Kligman, 1998: p.7). Because the younger population, which was expected to constitute the labor force, had increasingly been shrinking, the Romanian government initiated a set of programs to reverse the declining fertility trends. In these programs, constraints about the use of contraceptive methods and an abortion ban were the major measures. In addition, some complementary measures, such as maternity leave, rewarding children-rich women with medals, tax reductions and payments, obstructions to divorce, were also taken.

With Decree number 770, the abortion ban, which had a distinctive role in population policy in Romania, was introduced on November $1^{\text {st }}, 1966$. However, the decree did exclude women who had already borne more than four children, who had conceived through an assault, whose birth-giving had been considered to be medically unfavorable, or who were determined to be physically, psychologically and 
emotionally ineligible for children. . Outside of these exemptions, doctors who performed abortions and women who sought them might have been sentenced to penalties (David, 1970 as cited in Legge \& Alford, 1986). The president of the period, Ceausescu, stated that "it is every healthy Romanian woman's patriotic duty to have four children" (Legge \& Alford, 1986: p.725) and added that "the fetus is the property of the entire society. Anyone who avoids having children is a deserter who abandons the laws of national continuity" (Breslau, 1990 as cited in Newman \& Grauerholz, 2002: p.328). According to Kligman (1998: p.7), Ceausescu was instrumentalizing the female body in order to realize his goals.

Briefly, the consequences of the decree were very severe. A great many women suffered from self-induced abortions and orphanages overflowed with unwanted and unhealthy babies (Newman \& Grauerholz, 2002: p.328). In addition, a rapidly emerging cohort would require more resources for schooling, shelter and employment. Given the fact that these are state-provided facilities, an appropriate economic plan should have been introduced by the state well before the initialization of the population policy. Moreover, the crude birth rate, which had been 14,3 before 1966, has increased to 27,4 within a year. Especially during the two years following the decree, a significant decline in the number of legal abortions was observed. However, this decline was limited to the years when a rigid control over abortions was implemented. As a result, the crude birth rate fell again to 18,4, a rate which was close to the rates of other Eastern European countries where restrictions over birth control methods and abortion ban did not exist.

\section{The Development of Antinatalist Policies in China}

"China's population grew rapidly in the 1950s and 1960s, and by the 1970s it had increased by some 250 million since the founding of People's Republic" (Basten \& Jiang, 2014: p.493). High fertility and declining mortality together accounted for the rapid population growth. Mortality decline occurred especially among children and younger adults (Peng, 2011). As demographic transition theory has shown elsewhere, such a combination of high fertility and low mortality would cause a population to boom and to continue to grow until fertility rates begin to decline. As a matter of fact, the demographic annual growth rate of China was more than $2 \%$ between the 1950s and the 1970s (ibid: p.581). In response to such growth, the "Chinese government was involved in birth planning in the 1950s" (Riley, 2004: p.11).

It should also be kept in mind that during the initial period of the foundation of People's Republic of China, population growth was desired in order to gain political 
strength and to provide a labor force. Soon after, however, in the mid-1950s, the government reversed its position in seeking development in economic and health realms (ibid, p. 11). In fact, "China was an example of the contradiction between rhetoric and action evident in Bucharest", where the first World Population Conference organized by the United Nations was held (Feng, Gu \& Cai, 2012: p.116). In the conference held in 1974, the Chinese delegation pronounced an antiimperialist and anti-colonialist attitude towards super-powers with respect to development (Demeny, 1985: pp.99-100), despite the fact that at the same time in China "a nationwide birth control program was already well underway" (Feng et al., 2012: p.117).

The birth control program of the 1970s included "restrictions on family size, late marriage and childbearing, and the spacing of children" (Hesketh, Lu \& Xing, 2005: p.1171). This was also known as the wan xi shao or "fewer, later, longer" campaign, which was undertaken through mass propaganda (Nie \& Wyman, 2005: p.315), throughout the 1970s (Greenhalgh \& Bongaarts, 1987). Because of the economic stagnation of the Cultural Revolution in China, the Chinese government launched a one-child policy. In the aftermath of Mao's leadership, economic development was determined to be the fundamental basis of the new leadership's political legitimacy. The main concern was to increase per capita GDP growth (Feng et al., 2012: p.118). In 1979, the official Chinese news outlet reported that couples would be allowed to have one child, with at most two (Feng et al., 2012: p.118). The one-child policy was announced in the Open Letter to the members of the Communist Party of China and the Communist Youth League (Feng et al., 2012; Basten \& Jiang, 2014). The government's birth planning policies became more restrictive in the 1980s (Riley, 2004: p.11). With the one-child policy, the Chinese government targeted a population of 1.2 billion by the year 2000 (Hesketh et al., 2005; Feng et al., 2012).

The total fertility rate in China was about 5,8 in 1970; it dropped sharply to 2,8 in 1979 (Peng, 2011: p.581), the year when the one-child policy was initiated. This would evidently mean that a considerable part of the fertility decline had already started before the government began to implement its family planning program. "Although the fertility rate had fallen to less than half that level by the late 1970s, in 1979-1980 China introduced its one-child birth planning policy to reduce the country's rapid population growth" (Nie \& Wyman, 2005: p.313). Actually, fertility rates had already begun to decline as early as in the 1950s and the 1960s, probably because the government paid special attention to urban fertility, and because families themselves began to desire fewer children (Riley, 2004: p.11). The decline up until 1979 was partly due to "advances in education, improvements in the position of women, and reductions in mortality" (Peng, 2011: p.582), which may be interpreted as a natural outcome of the modernization process. It is also widely discussed in the 
literature that even without introducing such a policy, birth rates would naturally have fallen to the fertility level of other countries that had had birth rates similar to that of China before the policy was enacted (Feng et al., 2012; Hesketh, Zhou \& Wang, 2015).

However, only after the one-child policy was initiated did the total fertility rate drop below the replacement fertility level, which it did by the early 1990s (United Nations, 2017). This decline appeared more gradually, and it stabilized at a total fertility rate of about 1,7 (Wang, 2003; as cited in Hesketh et al., 2005). The overall fertility decline that took place within a few decades in China is considered in the demographic literature to be the most rapid one ever observed in any human population (Lavely, 1984) and the government's effort is considered as the most prominent effort to control population growth ever seen (Feng et al., 2012). "There is no doubt that government commitment, and the efficient and sometimes coercive implementation of the family planning program, were the major determinants of China's rapid fertility decline" (Peng, 2011: p.581).

The one-child policy was designed through a set of incentives and disincentives. These included educational opportunities, health care, housing and job assignments as rewards on the one hand, and punishments such as fines or no access to education and other privileges granted otherwise, on the other (Riley, 2004: p.12). It should also be noted that the one-child policy was limited basically to urban families and the majority of rural families were freer to have up to two children (Peng, 2011: p.582), especially if their first child was a girl and/or if the second child was born after five years (Hesketh et al., 2005: p.1171). In 1984 and 1985, birth planning policy began to be eased in part because of the success of the policies and the rapid shrinking of family size. This is evident in that the Central Committee changed the well-known population target for the year 2000 from 1.2 billion to "about" 1.2 billion (Greenhalgh \& Bongaarts 1987: p.1167). By 1989, it was argued that the family planning policy of China had been relaxed to some extent (Yi, 1989). Moreover, Basten and Jiang (2014: p.494) state that due to the economic, social and demographic heterogeneity of China, most provinces and even the villages had been permitted to follow their own birth control implementations from the mid-1980s onward.

According to Feng et al. (2012: p.115-116), China's one-child policy was the most draconian government social engineering ever seen. They also argue that an examination of this intervention offers valuable lessons on the role of the politics in birth control. Before discussing the demographic consequences of the one-child policy, one tragic effect it produced upon individual lives should be pointed out: "More fundamentally, it is seen as an ill-conceived policy that has prevented Chinese 
individuals and families from having the number of children they desire" (ibid: p.123). The Chinese one-child policy should be considered to be on the same plane with the Romanian pronatalist case, in that it is another form of intervention to human bodies - similar in terms of the effects upon individuals. Other long-lasting macro and micro demographic effects are discussed below.

First of all, the policy caused a sex ratio imbalance in China. The sex ratio at birth ${ }^{4}$ is normally about 105, the ration that China had in 1979. In the aftermath of the introduction of the one-child policy in 1979, the ratio displayed a steady increase to 111 in 1987 and to 114 in 1989 (Yi, Ping, Boachang, Yi, Bohua \& Yongpiing, 1993). It has also been argued that the sex ratio at birth in some rural parts of China was as high as 130 (Kang \& Wang, 2003 as cited in Hesketh \& Xing, 2006: p.13273). This is mostly due to sex-selective abortion (Coale \& Banister, 1994; Attané, 2009) and underreported female births (Merli \& Raftery, 2000).

Secondly, the restriction on family size would mean that caregiving for the elderly would be a problem with long-lasting effects on Chinese families. Being a rapidly aging population due to low fertility and increasing life expectancy, the Chinese population is composed of a great number of old people who are in need of care. In fact, Chinese culture is noted for a care ethic which is known as filial piety. Chinese society relies on the family, instead of on welfare provisions of the state, for providing caregiving for the elderly. It is particularly the male adult children who are traditionally expected to support elderly parents in Chinese culture, although today children of both sexes are legally considered to be responsible for it (Greenhalgh \& Bongaarts, 1987: p.1169). Written governmental policies and tax provisions encourage adult children to co-reside or keep aging parents nearby (Liu, 2000: p.196). Problems in caring for the aging population are exacerbated by the fact that increasingly far fewer adult children will be available for elder care as a result of the one-child policy. Moreover, the unbalanced sex ratio may have some indirect effects on elder care within the family. Fewer eligible women could mean that more and more older males, who will remain unmarried throughout their life course, will lack family support and there will be "many more parents who will not have a daughter-in-law to care for them" (Zhang \& Goza, 2006: p.153).

Thirdly, it can also be speculated that maternal and neonatal mortality may increase due to the fact that "many deliveries of babies that have not been officially sanctioned occur at home without trained personnel" (Hesketh et al., 2005: p.1172). This is because families may avoid reporting births in order to have a right to register their -in name- only child. By drawing upon data from research conducted in Sichuan, Ni

\footnotetext{
${ }^{4}$ The number of male live births for every 100 female live births.
} 
and MacKay Rossignol (1994) argue, that the risk for maternal mortality is higher for the unregistered pregnancies and births, due to the fact that women with unregistered pregnancies avoid prenatal care and the deliveries may be attended by non-medical personnel, as a consequence of the one couple-one child policy.

The one-child policy of China "has profoundly affected the lives of one-fifth of the world's population for 35 years, at the most personal level of reproductive choice" (Hesketh et al., 2015: p.2619). Since January 1, 2016, the date the policy was ended, Chinese couples have been allowed to have two children (Feng, Gu \& Cai, 2016).

\section{Conclusion}

With regard to the control of the body, employing any sort of bio-political means would mean that human will is ignored. The psychology and physiology of the body may be severely affected especially when these bio-political means are exercised in fertility-related processes. Clearly, coercive and oppressive fertility policies that governments enact may threaten human lives. This is true for both pronatalist and antinatalist policies.

Interventions into human fertility through population policies may be regarded as bio-politics from a Foucauldian perspective. Humankind moved from an era when the body was disciplined by the threat of death to an era when the body is controlled by subtler and pseudo-humane policies. It must be noted here that Foucault's biopolitical means should be categorized into two sets, as encouraging and coercive means. Democratic governments, such as in Scandinavian countries, which respect human will, may also employ bio-political means within comprehensive family policies (Güvenç \& Karaman, 1991: p.105-188), however they do not attempt to dominate bodies. Likewise, since its foundation to today, population policies in Turkey have perpetually ensured the autonomy of the individual and the family. Besides, even in periods when population is of greater importance as an economic resource, Turkish population policies have never been based on coercion and oppression. Therefore, without exception, all of the population policies that have been enacted in different periods in Turkey may be regarded as encouraging policies. By contrast, reproduction as a personal concern was politicized by weakly democratic governments, as experienced in the cases of Romania and China for the periods discussed above.

Foucault's claim that control over the body in modern society with the discovery of the issue of "population" might be instantiated in governmental population policies. Especially when they are based on coercion and oppression, pronatalist and 
antinatalist policies should be seen as bio-political means. From a Foucauldian view, this study is an attempt to reveal the consequences experienced through the pronatalist policies of Romania between 1966 and 1989 and the antinatalist policies of China between 1979 and 2016. Some implications for the individual cases and the overall effects of such population policies are drawn from this study.

In Romania, a peculiar era began in 1966 when Decree number 770 was launched. The Ceausescu regime between 1966-1989, which had followed a pronatalist policy in the most restrictive way ever seen in world history, caused tragic effects on the Romanian population (Kligman, 1998: p.2). The policy and its effects became prominent through a set of strategies to control the body and specifically to regulate the reproductive behavior of individuals. An abortion ban, limited access to contraceptive techniques, and a set of incentives, such as extended maternity leaves, medals for children-rich women and family allowances were practical implementations of Romanian pronatalist approach. Among all of the pronatalist means, it was particularly the abortion ban that caused an increase in the number of maternal deaths. Indeed, the maternal mortality rate in 1989 in Romania reached a peak, the highest ever recorded in the European demographic history. The most important factor for maternal deaths was illegal abortions (ibid: p.8, 215). Throughout the years when access to contraceptive techniques was obstructed, if not totally banned, unwanted pregnancies led to unwanted babies, which in turn caused an enormous increase in the number of children left to orphanages. Being one of the Eastern European countries where development of the labor force was desired for an economic push in the post-war period, Romania succeed only for a limited period of time in reaching high fertility, despite of all of these measures taken.

Although its goals were quite the opposite, the implications of China's pronatalist policies are similar to those of antinatalist ones. For more than three decades, China witnessed an antinatalist program, by which couples were only allowed one child. The one-child policy was launched in 1979 and remained in force until 2016. Not only incentives, such as educational opportunities, health care, housing and job assignments were used; but also, disincentives, such as fines or restricted access to education and other privileges granted otherwise were put into effect in order to sustain the program. The policy had profound social, economic and demographic effects on the Chinese population. Although about 400 million births were prevented through the one-child policy, it has also been observed in the literature that in any case, even in the absence of the policy, fertility rates would have fallen. The already discussed negative consequences of the policy have been a rapidly aging population, shrinking support for the elderly, an increased risk for maternal and neonatal mortality and a sex ratio imbalance. The unbalanced sex ratio is mostly due to relinquishing female children, in a cultural setting where male children are cherished. 
As a result, from 1970 onwards, the sex ratio at birth has steadily increased and China has the highest sex ratio at birth in the world today (United Nations, 2017).

Besides the fact that when and how many children individuals desire to have is quite intimate, reproduction itself is a basic human right. The pronatalist and antinatalist policies of Romania and China politically blurred the borders between the public and private spheres, ideationally eroded human will and human agency, and vitally threatened the female body, the fetus and even the societal entity as a whole.

\section{References}

Attané, I. (2009) The Determinants of Discrimination Against Daughters in China: Evidence from a Provincial-Level Analysis. Population Studies 63 (1), 87-102.

Basten, S. \& Quanbao J. (2014) China's Family Planning Policies: Recent Reforms and Future Prospects. Studies in Family Planning, 45 (4), 493-509.

Beck, U. \& Beck-Gernsheim E. (2004) The Normal Chaos of Love. Malden, Polity Press.

Beck, U. (2014) Risk Toplumu: Başka Bir Modernliğe Doğru. İstanbul, İthaki Yayınları.

Berelson, B. (1979) Romania's 1966 Anti-Abortion Decree: The Demographic Experience of the First Decade. Population Studies 33 (2), 209-222.

Besemeres, J. F. (1980) Socialist Population Politics: The Political Implications of Demographic Trends in the USSR and Eastern Europe. New York, M.E. Sharpe Inc., White Plains.

Caldwell, J. C. (2005) On Net Intergenerational Wealth Flows: An Update. Population and Development Review 31 (4), 721-740.

Caldwell, J. C. (1976) Toward a Restatement of Demographic Transition Theory. Population and Development Review 2 (3-4), 321-366.

Coale, A. J. \& Banister J. (1994) Five Decades of Missing Females in China. Demography 31(3), 459-479.

Curtis, B. (2002) Foucault on Governmentality and Population: The Impossible Discovery. The Canadian Journal of Sociology 27(4), 505-533.

Demeny, P. (1985) Bucharest, Mexico City, and Beyond. Population and Development Review 11 (1), 99-106.

Fanti, L. \& Gori L. (2009) Population and Neoclassical Economic Growth: A New Child Policy Perspective. Economics Letters 104 (1), 27-30.

Feng, W., Gu B. \& Cai Y. (2016) The End of China's One-Child Policy. Studies in Family Planning 47 (1), 83-86.

Feng, W., Cai Y. \& Gu B. (2012) Population, Policy, and Politics: How Will History Judge China's One-Child Policy? Population and Development Review 38 (Supplement), $115-129$.

Foucault, M. (1992) Ders Özetleri: 1970-1982. (Trans. Selâhattin Hilav). İstanbul, Yap1 Kredi Yayınları.

Foucault, M. (1978) The History of Sexuality, Volume 1: An Introduction. New York, Pantheon Books.

Giddens, A. (2010) Modernite ve Bireysel Kimlik: Geç Modern Çă̆da Benlik ve Toplum. (Trans. Ümit Tatlıcan) İstanbul, Say Yayınları.

Giddens, A. (2005) Sosyoloji: Kısa Fakat Eleştirel Bir Giriş. (Trans. Ülgen Yıldız Battal) Ankara, Phoenix Yayınevi. 
Greenhalgh, S. \& Bongaarts J. (1987) Fertility Policy in China: Future Options. Science, New Series 235. 4793, 1167-72.

Güvenç, N. \& Karaman L. (1991) Kapsamlı Aile Politikaları Uygulayan Ülkeler: İsveç Aile Politikaları: Karşılaştırmalı Ülkeler Panoraması. Ankara, T.C. Başbakanlık Aile Araştırmaları Kurumu Başkanlığı Yayınları, 105-118.

Hesketh, T. \& Xing Z. W. (2006) Abnormal Sex Ratios in Human Populations: Causes and Consequences. PNAS 103. 36, 13271-13275.

Hesketh, T., Lu L., \& Xing Z. W. (2005) "The Effect of China's One-Child Family Policy after 25 Years." New England Journal of Medicine 353, 1171-1176.

Hesketh, T., Zhou X. \& Wang Y. (2015) The End of the One-Child Policy: Lasting Implications for China. Journal of the American Medical Association, 314. 24, 2619-2620.

Johnson-Hanks, J. (2008) Demographic Transitions and Modernity. Annual Review of Anthropology 37, 301-315.

Kağıtçıbaşı, Ç. (1982) The Changing Value of Children in Turkey (Papers of The East-West Population Institute No: 60). Honolulu, Hawaii, East West Center.

Kligman, G. (1998) The Politics of Duplicity: Controlling Reproduction in Ceausescu's Romania. USA, University of California Press.

Lavely, W. R. (1984) The Rural Chinese Fertility Transition: A Report from Shifang Xian, Sichuan. Population Studies 38 (3), 365-384.

Legge, J. S., \& Alford J.R. (1986) Can Government Regulate Fertility? An Assessment of Pronatalist Policy in Eastern Europe. The Western Political Quarterly 39 (4), 709728.

Lenin, V. (2000) Marksizm, Kadın ve Aile. (Trans. Ömer Ünalan) Ankara, Bilim ve Sosyalizm Yayınları.

Liu, W. T. (2000) Values and Caregiving Burden: The Significance of Filial Piety in Elder Care. Who Should Care for the Elderly: An East-West Value Divide. (Eds. William T. Liu and Hal Kendig). Singapore, Singapore University Press, 183-199.

Macura, M. (1974) Population Policies in Socialist Countries of Europe. Population Studies 28(3), 369-379.

McIntryre, R. J. (1975) Pronatalist Programmes in Eastern Europe. Soviet Studies 27 (3), 366-380.

Merli, M. G. \& Raftery A.E. (2000) Are Births Underreported in Rural China? Manipulation of Statistical Records in Response to China's Population Policies. Demography 37 (1), 109-126.

Moskoff, W. (1980) Pronatalist Policies in Romania. Economic Development and Cultural Change 28 (3), 597-614.

Newman, D. \& Grauerholz L. (2000) Sociology of Families. London, Sage Publications.

Ni, H. \& MacKay Rossignol, A. (1994) Maternal Deaths Among Women with Pregnancies Outside of Family Planning in Sichuan, China. Epidemiology 5 (5), 490-494.

Nie, Y. \& Wyman R. J. (2005) The One-Child Policy in Shanghai: Acceptance and Internalization. Population and Development Review 31(2), 313-336.

Önder Erol, P. (2011) Sosyolojik Perspektiften Demografik Yaşlanma: Toplumsal, Ekonomik ve Politik Alanlarda Yaşlı Failliği. Unpublished Diss. (Ph.D. Thesis). Ege Üniversitesi Sosyal Bilimler Enstitüsü.

Peng, X. (2011) China's Demographic History and Future Challenges. Science 333. 6042, 581-587.

Riley, N. E. (2004) China's Population: New Trends and Challenges. Population Bulletin 59 (2), 1-38. 
Szreter, S, Nye R. A. \& van Poppel F. (2003) Fertility and Contraception During the Demographic Transition: Qualitative and Quantitative Approaches. The Journal of Interdisciplinary History 34 (2), 141-154.

Teitelbaum, M. S. (1972) Fertility Effects of the Abolition of Legal Abortion in Romania. Population Studies 26 (3), 405-417.

United Nations (2017) Department of Economic and Social Affairs, Population Division 2017. "World Population Prospects: The 2017 Revision" 12 June 2017. <https://esa.un.org/unpd/wpp/DataQuery/ >. [Accessed 12th June 2017]

Van de Kaa, D. (1987) Europe's Second Demographic Transition. Population Bulletin 42 (1), 3-57.

Yi, Z. (1989) Is the Chinese Family Planning Program 'Tightening Up'?. Population and Development Review 15 (2), 333-337.

Yi, Z., Ping T, Gu B., Yi, X, Bohua L. \& Yongpiing L. (1993) Causes and Implications of the Recent Increase in the Reported Sex Ratio at Birth in China. Population and Development Review 19 (2), 283-302.

Zhang, Y., \& Goza F. W. (2006) Who Will Care for the Elderly in China? A Review of the Problems Caused by China's One-Child Policy and Their Potential Solutions. Journal of Aging Studies 20, 151-164. 